\title{
Cholelithiasis and ayurveda
}

\begin{abstract}
Cholelithiasis in female is increasing rampantly among obese, ${ }^{1,2}$ hyperlipidemic and hypo functioning thyroid women who undergone tube ligation or hysterectomy may be synergized by increasing toxic non nutrients in diet and changed life style, Common surgical preference Cholecystectomy and Choledochotomy though relieve the agonizing pain but alter digestion permanently which predisposes for the continuance of the presentation like heaviness in the abdomen, heart burn, eructation, lethargy, bowel irregularity in spite of dietary restriction.

Placebo based control study to evaluate a herb mineral composit in 216 cases affirm its worth in relieving clinical presentation and USG confirmation in majority cases with grade I clinical response while control group shows only transient symptomatic relief. 3years post therapy follow up and dietary restriction with maintenance dose of 1 pill daily, none had any bowel irregularity or any evident cholelithiasis or hyperlipidemia.
\end{abstract}

Keywords: cholelithiasis, hyperlipidemia, cholecystectomy, choledochotomy, herbomineral

\section{Introduction}

To curb the rising population female sterilization in early age and a trend of hystrectomy for monetary lust, poses an increased problem of hormonal imbalance resulting in thyroid hypo function and altered calcium metabolism. Thyroid hypo function not only alter the Calcium metabolism but also cause bile concentration leading to Cholelithiasis, as a dictum female, fatty and fourty most commonly prone for cholelithiasis ${ }^{3-5}$ and present with eructation, heart burn, indigestion, heaviness and pain in the abdomen. In addition changed diaetary and life style also alter the normal digestion and metabolic process due to non nutrient toxic constituent of the food and drinks. ${ }^{6-9}$

The bile super saturation with cholesterol is a key factor of cholelithiasis. The gold standard treatment for symptomatic gall bladder stone is laproscopic cholecystectomy or Oral litholysis remain restricted for few basophilic bile acids i.e- Oral litholytic Urso deoxycholic acid faces a problem of recurrence of gall stone in 5yrs and risk of surface calcification cholestrol gall stones in about $10 \%$ cases .Statin posses competitive inhibition of 3 -Hydroxy-3-methyl glutaryl Co A reductase ${ }^{10,11}$ which reduces biliary cholesterol ability to suppress hepatic cholesterol gall stone formation.

This agonizing condition usually compel the patients to undergo surgical intervention i.e. Cholecystectomy which alter the digestion of protein and fat permanently due to deficient bile in the duodenum required for activation of protein and fat digesting enzymes secreted from the pancreas. ${ }^{12-21}$

Thus to save the patients from agonizing and costly surgical procedure and their consequent lifelong presentation due to altered protein and fat digestion, ${ }^{22,23}$ a herbomineral therapeutic modality was evolved with an intent to liquefy the bile, check ability to formation of gall stone and lysis of cholelith with cholekinesis to ensure natural transport of bile to duodenum and bioregulation and maintenance of normal digestive process.

\section{Material and methods}

\section{Design of study}

Placebo based controlled comparative evaluation.
Volume 7 Issue 5 - 2017

\author{
Avinash Shankar,' Amresh Shankar,' \\ Anuradha Shankar ${ }^{3}$ \\ 'Chairman, National Institute of Health \& Research, India \\ ${ }^{2}$ Bihar State Health Services, India \\ ${ }^{3}$ Director, Centre for Research in Indigenous Medicine, India
}

Correspondence: Avinash Shankar, MD (Internal Medicine), Chairman, National Institute Of Health \& Research, Warisaliganj (Mawada) Bihar, 805I30, India, Email dravinashankar@gmail.com

Received: June 22, 2017 | Published: July 05, 2017

\section{Material}

Patients presenting with the features suggestive of Cholelithiasis attending at Medical OPD of RA Hospital \& Research Centre during January 2012-2013 been selected and duly confirmed by clinical examination, ultrasonography and cholecystography. Patients of acute onset not responding to conservative line of therapy been not included in the study.

\section{Clinical presentation}

a. Sporadic and unpredictable episodes.

b. Localized pain in epigastrium, right upper quadrant, occasionally radiate to the right scapular tip.

c. Pain that start after taking food intense and dull, typically last for 1-5hours, increases steadly over 10-20minutes and gradually wanes.

d. Constant pain unrelieved by emesis, antacid and passing stool usually associated with perspiration, nausea and vomiting.

e. Indigestion, dyspepsia, belching and bloating.

Patients were thoroughly interrogated and investigated to establish the diagnosis and record the base line status of hemato, hepato and renal status to adjudge therapeutic efficacy and safety profile.

Selected patients were graded as per their clinical presentation as-

\begin{tabular}{ll}
\hline Clinical grades & Presentation \\
\hline Mild & $\begin{array}{l}\text { Over weight, eructation, vomiting, heart burn, } \\
\text { heaviness in the abdomen } \\
\text { Duration }<1 \text { year }\end{array}$ \\
& $\begin{array}{l}\text { Over weight, eructation, vomiting, heart burn, } \\
\text { heaviness in the abdomen, } \\
\text { Abdominal pain, } \\
\text { Doderate }\end{array}$ \\
& $\begin{array}{l}\text { Agonising abdominal pain , restricted movement, } \\
\text { loss of sleep }\end{array}$ \\
Severe & Duration $>2$ yrs
\end{tabular}




\section{Method}

Selected patients were classified in two equal groups comprising 108 cases in each to adjudge the clinical efficacy of the used indigenous composite and its safety profile as compared to conventional therapy.

Study group (Group A): Conventional conservative therapy with indigenous composite pill in dose of 1 pill three times daily.

Control group (Group B): Conventional therapy and placebo. Both groups were advised similar dietary restriction. Base line hepato renal and lipid profile been done to adjudge post therapy effect or alteration.

Each selected cases were advised and assured adjuvant pills prepared with required indigenous composite to ensure prompt check on presenting feature

Herbo mineral adjunct is prepared as per follows

Constituents

Aloe vera pulp (dried powder) 100gm

Borax (Sodium borate) fried powder 50gm

Papaya (Carica papaya root) extracts $25 \mathrm{ml}$

Pathharchoor (Bergamia ligulata) leaf extract $25 \mathrm{ml}$

\section{Process}

Fresh pulp of Aloe vera Indica leaf is dried in a ghreet painted pan to make dry powder of the pulp. Fried Sodium borate is powdered and a mixed with the Aloe vera pulp powder, to which extract of Carica papaya root and Bergamia ligulata leaf added and triturated to prepare pills of pea nut size.

\section{Dose}

1 pill three times daily with luke warm water.

\section{Dietary restriction}

a. No milk, non vegetarian diet.

b. Restrict oil and fats.

c. Avoid chillies and condiment

\section{Conventional or conservative treatment constitutes}

f. Proton pump inhibitor to check hyperacidity.

g. Improve digestive function and intestinal load by avoiding protein and fat rich diet.

h. Antacid gel to retain alkalinity of the intestinal content.

i. Drugs to adjunct hepatic function and promote bile solubility.

j. Analgesics drugs to promptly check the agonizing abdominal pain.

k. In acute cases intravenous fluid to compensate fluid load and provide rest and energy.

Patients were given follow up card to enter clinical response or any adversity during therapy and present at the centre or contact project officer.
Follow up card :

Name of patient:Age

Address :

Date of ligation : Hystrectomy:

\section{Particulars Days}

Pain in abdomen

Vomiting

Heaviness in the abdomen

General debility

Change in urine color

Change in stool color

Any other

Based on the clinical response and record of the follow up card the therapeutic effect was graded as-

\section{Response grade characteristics}

Gr I No recurrence of pain in abdomen and alleviation of all the Presenting complaints without any alteration in hepato renal and Hematological parameters.

Gr II Relief of pain but presence of heaviness in the abdomen, appetite none improved.

Gr III Transient relief in abdominal pain with recurrence.

All cases who reported complete relief of presentation under gone for repeat ultra sonography abdomen to assess the status of choleliths and investigated for hematological and hepato renal parameters to adjudge the safety profile.

\section{Observation}

Selected patients were of age group 25-45 and majority (35.6\%) were of age group 35-40yrs (Table 1) and as per duration of illness $12.5 \%$ were having complaint $<1 \mathrm{yr}$ while $23.4 \%$ were from $>5 \mathrm{yrs}$ (Table 2).

Patient's most common presentations are agonizing abdominal pain, heaviness in the abdomen in majority cases while some also presented with manifestation suggestive of obstetric jaundice (Table-3).

All patients were obese and $45 \%$ were with severe obesity having body weight $>1.5$ times Ideal Body Weight (Table 4 ). As per clinical severity $65.7 \%$ were of moderate and $21.3 \%$ were of severe grade of clinical presentation (Table 5).

Table I Distribution of patients as per age group

\begin{tabular}{ll}
\hline Age group (in Years) & Number of patients \\
\hline $25-30$ & 59 \\
$30-35$ & 48 \\
$35-40$ & 77 \\
$40-45$ & 32 \\
\hline
\end{tabular}

Table 2 Distribution of patients as per duration of illness

\begin{tabular}{ll}
\hline Duration of Illness (in Years) & Number of patients \\
\hline$<I$ & 27 \\
$I-2$ & 32 \\
$2-3$ & 44 \\
$3-4$ & 22 \\
$4-5$ & $4 I$ \\
$>5$ & 50 \\
\hline
\end{tabular}


Table 3 Distribution of patients as per presentation

\begin{tabular}{ll}
\hline Common presentation & Number of patients \\
\hline Agonizing abdominal pain & 178 \\
Eructation & 216 \\
Nausea & 198 \\
Heart burn & 216 \\
Indigestion & 216 \\
Froathy stool & 192 \\
\hline
\end{tabular}

Table 4 Distribution of patient as per their obesity state

\begin{tabular}{llll}
\hline \multirow{2}{*}{ Age Group (In Yr) } & \multicolumn{3}{l}{ Number of Patients Obesity Status } \\
& Mild & Moderate & Severe \\
\hline $25-30$ & 9 & 19 & 31 \\
$30-35$ & 10 & 11 & 27 \\
$35-40$ & 19 & 32 & 26 \\
$40-45$ & 8 & 11 & 13 \\
\hline
\end{tabular}

Table 5 Distribution of patients as per severity of illness

\begin{tabular}{ll}
\hline Clinical severity & Number of patients \\
\hline Mild & 28 \\
Moderate & 142 \\
Severe & 46
\end{tabular}

Hepatic parameter is altered in 26 cases where as lipid profile in 199 cases and all had hypothyroidism $(\mathrm{TSH}>10)$ (Table 6). Majority patients of group A show grade I clinical response with complete absence of Cholelith in USG while in group B majority had grade III response with 1 case showing cholelith disintegration in USG. All patients of Group A had improved status of hematological, lipid, hepatic and renal profile while group B patients show marked alteration (Table 7).

Table 6 Distribution of patients as per their biochemical status

$\begin{array}{ll}\begin{array}{l}\text { Blochemical parameters } \\ \text { Hematological: }\end{array} & \text { Number of patients } \\ \text { Hemoglobin } & \\ \quad<10 \mathrm{gm} \% & \\ \quad>10 \mathrm{~mm} \% \\ \text { Hepatic profile: }\end{array}$

Table 7 Shows outcome of the therapy

\begin{tabular}{|c|c|c|}
\hline Particulars & $\begin{array}{l}\text { Number } \\
\text { group A }\end{array}$ & Group B \\
\hline \multicolumn{3}{|l|}{ Clinical response: } \\
\hline Grade II & 105 & - \\
\hline Grade III & 03 & - \\
\hline Ultrasonography: & - & 108 \\
\hline Presence of cholelith & - & 107 \\
\hline Absence of Cholelith & 107 & - \\
\hline Disintegeration phase & 01 & 01 \\
\hline Relapse/recurrence in 3yrs & None & 107 \\
\hline Persistence & None & 107 \\
\hline $\begin{array}{l}\text { TSH } \\
<5.5\end{array}$ & 108 & 92 \\
\hline$>5.5$ & - & 16 \\
\hline \multicolumn{3}{|l|}{ Safety profile: } \\
\hline \multicolumn{3}{|l|}{ Hepatic: } \\
\hline SGOT & 108 & 31 \\
\hline$<40$ & - & 77 \\
\hline$>40$ & 108 & 31 \\
\hline SGPT & - & 77 \\
\hline \multicolumn{3}{|l|}{$<40$} \\
\hline$>40$ & & \\
\hline
\end{tabular}

\section{Discussion}

Cholelithiasis is increasing among women undergone sterilization or hysterectomy due to obesity and weight gain as a result of increased Thyroid stimulating Hormone concentration and hypo function of thyroid. ${ }^{24,25}$ In addition altered dietary nutrient and changed life style predispose for the hyper billiary concentration with lithogenesis and present with encumbrance like eructation, heaviness in the abdomen, nausea, vomiting and pain in abdomen, compel the patient to seek urgent care to ensure relief of agonizing pain but cholecystectomy though relieve agonizing pain but make life agonizing permanently due to future altered protein and fat metabolism caused by absence of bile to activate protease and lipase secreted from pancreas.

The present study reveals marked and evident clinical supermacy of the indigenous composit in disintegeration of cholelith and its due excretion with bio regulated cholekinesis as compared to surgical cholecystectomy and ensures life time natural bowel bioactivity.

\section{The clinical achievement can be attributed to}

Potent lithotriptic or litholytic effect of active ingradient of Carica papaya root (Caricin ),Bergemia ligulata (Bergemin ) causes disintegeration of choleliths, Sodium borate flower facilitate biliary excretion and improve cholekinesis while active ingradient of Aloe vera indica (Aloin -emodin, aloetic-acid, anthranol, aloin A and B (or collectively known as barbaloin), isobarbaloin, emodin, ester of cinnamic acid), bioregulate lipid profile and serum cholesterol thus check cholelithiasis and dietary restriction and thyroid bioregulation ensure future symptom free life..$^{26,27}$

\section{Conclusion}

Women suffering with cholelithiasis had altered thyroid function,lipid profile presenting with various presentation taking indigenous herbomineral composit with dietary restriction had complete symptomatic relief with ultrasonographic evidence of absence of cholelith in majority cases with grade I clinical response whether only 1 patient of control group shows cholelith disintegeration in USG and transient relief of presentation with grade III clinical 
response. Thus Indigenous herbomineral composite prove worth in management of Choleliths.

\section{Acknowledgments}

None.

\section{Conflicts of interest}

Author declares the there are no conflicts of interest.

\section{Funding}

None.

\section{References}

1. Portincasa P, Moschetta A, Palasciano G. Cholesterol gallstone disease. Lancet. 2006;368(9531):230-239.

2. Kratzer W, Mason RA, Kächele V. Prevalence of gallstones in sonographic surveys worldwide. J Clin Ultrasound. 1999; 27(1):1-7.

3. O'Leary DP, Johnson AG. Future directions for conservative treatment of gallbladder calculi. Br J Surg. 1993;80(2):143-147.

4. Diehl AK, Sugarek NJ, Todd KH. Clinical evaluation for gallstone disease: usefulness of symptoms and signs in diagnosis. Am J Med. 1990;89(1):29-33.

5. Berhane T, Vetrhus M, Hausken T, et al. Pain attacks in non-complicated and complicated gallstone disease have a characteristic pattern and are accompanied by dyspepsia in most patients: the results of a prospective study. Scand J Gastroenterol. 2006;41(1):93-101.

6. Hofmann AF, Amelsberg A, vanSonnenberg E. Pathogenesis and treatment of gallstones. N Engl J Med. 1993;328(25):1854-1855.

7. Johnston DE, Kaplan MM. Pathogenesis and treatment of gallstones. $N$ Engl J Med. 1993;328:412(6)- 421.

8. Grundy SM, Barnett JP. Metabolic and health complications of obesity. Dis Mon. 1990;36(12):641-731.

9. Diehl AK. Epidemiology and natural history of gallstone disease. Gastroenterol Clin North Am. 1991;20(1):1-19.

10. Chapman BA, Burt MJ, Chisholm RJ, et al. Dissolution of gallstones with simvastatin, an HMG CoA reductase inhibitor. Dig Dis Sci. 1998;43(2):349-353.

11. Caroli-Bosc FX, Le Gall P, Pugliese P, et al. Role of fibrates and HMGCoA reductase inhibitors in gallstone formation: epidemiological study in an unselected population. Dig Dis Sci. 2001;46(3):540-544.

12. Attili AF, Carulli N, Roda E, et al. Epidemiology of gallstone disease in Italy: prevalence data of the Multicenter Italian Study on Cholelithiasis (M.I.COL.). Am J Epidemiol. 1995;141(2):158-165.
13. Portincasa P, Di Ciaula A, Wang HH, et al. Medicinal treatments of cholesterol gallstones: old, current and new perspectives. Curr Med Chem. 2009; 16(12):1531-1542.

14. Portincasa P, Moschetta A, Puglisi F, et al. Medical treatment of gallstone disease. In: Borzellino G, Cordiano C (Eds.), Biliary lithiasis. Basic Science, Current Diagnosis and Management. Milano: Springer Italia S.r.1; 2008. p. 149-157.

15. Portincasa P, Moschetta A, Petruzzelli M, et al. Gallstone disease: Symptoms and diagnosis of gallbladder stones. Best Pract Res Clin Gastroenterol. 2006;20(6):1017-1029.

16. Danzinger RG, Hofmann AF, Schoenfield LJ, et al. Dissolution of cholesterol gallstones by chenodeoxycholic acid. $N$ Engl $\mathrm{J} \mathrm{Med}$. 1982;286(1):1-8.

17. Tait N, Little JM. The treatment of gall stones. BMJ. 1995;311(6997):99-105.

18. Makino I, Shinozaki K, Yoshino K, et al. Dissolution of cholesterol gallstones by long-term administration of ursodeoxycholic acid. Nihon Shokakibyo Gakkai Zasshi. 1975;72(6):690-702.

19. Michele Pier Luca Guarino, Ping Cong, Michele Cicala, et al. Ursodeoxycholic acid improves muscle contractility and inflammation in symptomatic gallbladders with cholesterol gallstones. Gut. 2007;56(6):815-820.

20. Paumgartner G, Pauletzki J, Sackmann M. Ursodeoxycholic acid treatment of cholesterol gallstone disease. Scand J Gastroenterol Suppl. 1994;204:27-31.

21. Tint GS, Salen G, Colalillo A, et al. Ursodeoxycholic acid: a safe and effective agent for dissolving cholesterol gallstones. Ann Intern Med. 1982; 97(3):351-356.

22. Sackmann M, Niller H, Klueppelberg U, et al. Gallstone recurrence after shock-wave therapy. Gastroenterology. 1994;106(1): 225-230.

23. Pereira SP, Hussaini SH, Kennedy C, et al. Gallbladder stone recurrence after medical treatment. Do gallstones recur true to type. Dig Dis Sci. 1995;40(12):2568-2575.

24. Amaral JF, Thompson WR. Gallbladder disease in the morbidly obese. Am J Surg. 1985;149(4):551-557.

25. Grünhage F, Lammert F. Gallstone disease. Pathogenesis of gallstones: A genetic perspective. Best Pract Res Clin Gastroenterol. 2006;20(6):997-1015.

26. Shankar A. Pharmacological basis of indigenous therapeutics, active constituents pharmacokinetics. 1st edn. India: Bhalani publication; 2017.

27. Shankar A. Carica papaya root active constituents as litholytic and lithotriptic. Journal of Ayush, Govt of India. 2011. 